\title{
EXCELLENCE IN EDUCATION. EXCELLENCE IN ART EDUCATION?
}

\section{Karen Thomas}

The deluge of reports evaluating schools in the United States will undoubtedly have some effects on all aspects of education. The question is whether these effects will be detrimental, neutral, or constructive to the development of excellence in art education. In this paper I will give a brief evaluation of the likely effects of three reports: A Nation at Risk (1983), Horace's Compromise (1984), and The Paideia Proposal (1984). These reports represent three different approaches: a general statement with recommendations, an ethnographic approach that gives "the feel" of what is happening and could happen in education, and a philosophic statement and logical argument. I will then present an in-depth comparison between the view of the arts presented in The Paideia Proposal and the view espoused by Discipline-Based Art Education.

A Nation at Risk, disseminated by the National Commission on Excellence in Education, takes a very general look at education. The report, however, does not address the field of art education very strongly. The authors of the report are not against art education, but it is clear that art education is not very important to them. Art is not basic; it is a frill, something extra. What is really important are the New Basics: English, mathematics, science, social studies, and computer science. Whereas the New Basics are important enough to rate a specific explanation of what will be taught and specific recommendations of how many years of instruction will be required, art is grouped with other unspecified subjects and tacked on near the end of the recommendations. If art courses are taken at all by high school students the authors feel excellence must be demanded, but it is apparent that they feel there is no need for their report to 
bother with laying out standards.

A Nation at Risk could have a very negative effect on art education, not because the report purposely maligns art, but because it reinforces a very low priority for art education. This, coupled with the increased requirements for the New Basics, will mean that many talented students will not have time for art classes or will be advised away from them because they are not perceived to be as important as the New Basics.

In Horace's Compromise, Theodore Sizer takes us into the world of high school students and teachers. He not only makes statements about education, he helps us experience the worst and the best our high schools have to offer. Sizer does not mention art education specifically. He does, however, make some statements that could be used as arguments favoring art education. To a list of skills to acquire, quoted from The Paideia Proposal, Sizer adds "seeing," noting that "The visual, especially in our day, is as important as the linguistic, mathematical, and scientifc skills" (p. 99). This statement could be viewed as support for including the visual arts in education as a means of developing one aspect of students' abilities to see and evaluate what they see. In another statement, Sizer advocates a development of intuitive thinking and imagination. Sizer feels students need opportunities to be involved in trial-and-error problem solving that allows them to follow misdirected paths and learn to redirect their thinking. If models of qualitative problem solving are used, the making of art is especially useful in developing this type of thinking.

Although arguments for art eduction can be drawn from Sizer's statements, only an art educator or those supportive of art education probably would think of doing it. Sizer's book alone will not convince people of the importance of studying art. Sizer is, however, a member of the group that supports The Paideia Proposal. This proposal offers a much stronger support for the arts in public schools 
than A Nation at Risk or Horace's Compromise.

The Paideia Proposal, by Mortimer Adler, outlines a philosophically complete and consistent approach to education. Adler is a proponent of an education that is both liberal and general; that is, an education that is unspecialized and is the same for all. The proposal espouses three goals: acquisition of organized knowledge, development of intellectual skills or skills of learning, and enlarged understanding of ideas and values. The study of art is seen as one means to achieve these goals.

The proposal can be seen as elevating or lowering the status of art depending on how one views art education. The proposal raises the status of art by elevating it to an equal position with all other subjects that are taught in the public schools. In his explanation of the goal of acquisition of knowledge, Adler states that there are three areas of subject matter indispensable to basic schooling. One area is comprised of language, literature and fine arts. The other two areas are mathematics and natural sciences, and history, geography, and social studies. Adler feels that the language, literature, and fine arts area supplies indispensable knowledge about nature and culture. Thus, art is not considered an added frill as it is in many schools today. Although Adler gives the fine arts equal importance with other branches of knowledge, I note that in his more detailed explanation he deals solely with language. He does, however, give a more detailed account of the arts in a later section.

The goal of development of intellectual skills seems to deal primarily with quantitative learning, using verbal and numerical abilities. The goal of enlarged understanding of ideas and values deals with qualitative learning. It is with this last goal that the visual, musical, and performing arts are most directly connected. The materials used to achieve this goal include books and products of human artistry. The books include historical, scientific, and philosophical writings as well as poems, stories, and essays. The 
products of human artistry include individual music compositions, works of visual arts, plays, and productions in dance, film, or television. Emphasis is on individual works. This is an important point. The purpose of this learning is not to give an historical overview in any area of the arts, but to develop students' understanding and aesthetic appreciation. The method of teaching to be used is Socratic questioning. The group of students is to be small and active participation is crucial. By discussing individual items in depth students can learn to examine and understand ideas and values more clearly. They can learn to evaluate these ideas and values and to make personal decisions regarding them.

Adler's aim is to help students raise their minds from a state of "understanding or appreciating less to a state of understanding or appreciating more" (p. 30). To Adler, however, the making of art is not important in itself but as "the most direct means of developing art appreciation" (p. 30).

What would art education look like under The Paideia Plan? First, an important goal would be sharpening students' aesthetic appreciation abilities. The art program would be integrative in nature, focusing on all the arts, not just the visual arts or music. Individual works of art would be examined and evaluated. The aim would be for depth of understanding rather than breadth of knowledge. Students would be involved in art production activities such as painting pictures, performing plays, and writing poetry. The aim would be for a deeper understanding of the arts and the artistic process.

If one accepts the assumptions and goals of The Paideia Proposal then the art program suggested is logical and fitting. There is support for this viewpoint in the art education literature. The idea that in-depth study of individual works of art will affect students' abilities to perceive and appreciate other works of art has been suggested by some research (Wilson 1965). The idea that development 
of aesthetic appreciation should be the main goal of art education and that studio activities should serve as one means to that end has been suggested by Broudy (1976). Broudy has said that the skills of "impression" (aesthetic perception) should be developed to approximate those of the artist. The skills of "expression" (art making), however, should be taught in courses designed for non-artists. Technical standards would have to be relaxed to allow an individual to decide how much technique he or she wished to develop (p. 21).

From another viewpoint, The Paideia Proposal could be seen as lowering the status of art by not considering it a discipline to be taught in its own right. Currently the art education literature has been defining and elaborating the concept of Discipline Based Art Education or DBAE (Getty, 1985). Discipline Based Art Education takes roles and activities of professional artist, art historian, art critic, and aesthetician as models for outcomes for a visual arts education program. Clark and Zimmerman (1978) have outlined a structure for such a program that would take a student from a naive state to a sophisticated state that approximates that of the professional. Adler's goal is general education. He is not trying to develop scientists, mathematicians, artists, art critics, art historians, or aestheticians. He is trying to develop educated human beings.

At first glance, these two views appear to be in conflict. A second glance shows many similarities. Discipline Based Art Education is similar to The Paideia Proposal in its emphasis on acquisition of knowledge, development of skills, and enlargement of understanding. It is different in that it is art knowledge, art skills and art concepts that are emphasized rather than general knowledge, skills, and concepts. The educational end-in-view of DBAE is "educated adults who are knowledgeable about art and its production and responsive to the aesthetic properties of works of art and other objects" (Greer 1984, p. 212). The end product of DBAE and The Padeia Proposal is an 
educated person. DBAE stresses that the person be educated in depth in the visual arts.

Discipline Based Art Education is similar to The Padeia Proposal in its stress upon the integration of knowledge. Whereas the proposal seeks to integrate knowledge across disciplines, DBAE seeks to integrate knowledge within the visual arts. Possibilities and problems involved in integrating the roles of artist, art critic, art historian and aesthetician have been discussed in the literature (DiBlasio 1985, Lovano-Kerr 1985).

The Paideia Proposal and Discipline Based Art Education are similar in their goal to develop an educated person and in their emphasis on developing knowledge, skill, and understanding. They differ in the emphasis they give to scope and depth in the field of art. DBAE is a visual arts program. Paideia is a program for general education. The Paideia program views all the arts (literary, musical, visual, performing) as an integrated whole to be studied generally: DBAE views the visual arts as a separate discipline to be studied in depth.

In spite of their differences, each system could make use of features that are characteristic of the other. Those who wish to develop a Paideia system would find in DBAE the content, intellectual skills, and concepts needed to fill in the columns of the Paideia course diagram (Figure 1). Those who are developing a DBAE system might find the Paideia diagram useful in integrating features of the four roles within the visual arts. Each of the four roles offers knowledge to be acquired, skills that need to be developed, and ideas and values that need to be enlarged upon or understood. Didactic instruction could be used to transmit knowledge about art history, theories of criticism, and aesthetic theory. Coaching and supervised practice has always been part of developing art making skills and would also be beneficial in developing skills of reading, writing, and research in the areas of art history, art criticism, and aesthetics. 
The Same Course of Study for All

\begin{tabular}{|c|c|c|c|}
\hline & COLUMN ONE & COLUMN TWO & COLUMN THREE \\
\hline Gools & $\begin{array}{l}\text { ACQUISITION OF } \\
\text { ORGANIZED KNOWLEDGE } \\
\text { by meons of }\end{array}$ & $\begin{array}{l}\text { DEVEL OPMENT OF } \\
\text { INTELLECTUAL SKILLS } \\
\text { - SKILLS OF LEARNING } \\
\text { bY meons of }\end{array}$ & $\begin{array}{c}\text { ENLARGED UNDERSTANDING } \\
\text { OF } \\
\text { IDEAS AND VALUES } \\
\text { by means of }\end{array}$ \\
\hline Meons & $\begin{array}{l}\text { DIDACTIC INSTRUCTION } \\
\text { LECTURES AND RESPONSES }\end{array}$ & $\begin{array}{c}\text { COACHING, EXERCISES, } \\
\text { AND }\end{array}$ & $\begin{array}{c}\text { MAIEUTIC OR SOCRATIC } \\
\text { QUESTIONING }\end{array}$ \\
\hline - & $\begin{array}{c}\text { TEXTBOOKS } \\
\text { AND } \\
\text { OTHER AIDS } \\
\text { in three oreas } \\
\text { of } \\
\text { subject-matter }\end{array}$ & $\begin{array}{c}\text { SUPERVISED PRACTICE } \\
\text { in the } \\
\text { operations } \\
\text { of }\end{array}$ & $\begin{array}{c}\text { AND } \\
\text { ACTIVE PARTICIPATION }\end{array}$ \\
\hline$\frac{\text { Areas }}{\text { Operations }}$ & $\begin{array}{l}\text { LANGUAGE, LITERATURE, } \\
\text { AND }\end{array}$ & $\begin{array}{l}\text { READING. WRITING. } \\
\text { SPEAKING, LISTENING }\end{array}$ & $\begin{array}{l}\text { DISCUSSION OF BOOKS } \\
\text { (NOT TEXTBOOKS) AND }\end{array}$ \\
\hline and Activities & $\begin{array}{c}\text { THE FINE ARTS } \\
\text { MATHEMATICS } \\
\text { AND } \\
\text { NATURAL SCIENCE } \\
\text { HISTORY, GEOGRAPHY. } \\
\text { AND } \\
\text { SOCIAL STUDIES }\end{array}$ & $\begin{array}{l}\text { CALCULATING, } \\
\text { PROBIEM- SOLVING } \\
\text { OBSERVING.MEASURING, } \\
\text { ESTIMATING } \\
\text { EXERCISING CRITICAL } \\
\text { JUDGMENT }\end{array}$ & $\begin{array}{l}\text { OTHER WORKS OF ART } \\
\text { AND } \\
\text { INVOLVEMENT IN } \\
\text { ARTISTIC ACTIVITIES } \\
\text { Q.,. MUSIC, DRAMA, } \\
\text { VISUAL ARTS }\end{array}$ \\
\hline
\end{tabular}

THE THREE COLUMNS DO NOT CORRESPOND TO SEPARATE COURSES, NOR IS ONE KIND OF TEACHING AND LEARNING NECESSARILY CONFINED TO ANY ONE CLASS

Figure 1 
Maieutic or Socratic questioning is needed to help students discuss aesthetic theories and ideas and values of the past and in critiquing both their own art products and exemplary work of the past and present.

What will have the greatest effect on art education today? The Paideia Proposal is the only one of the three reports considered that makes a definite statement about art education. If adopted the arts will become a vital part of the public school curriculum, however, study of the visual arts as a discipline will be reserved for those who seek a career in the field and go on for higher education. In his second book, Paideia Problems and Possibilities: A Consideration of Questions Raised by the Paideia Proposal, Adler presents information about schools that are attempting to adopt a Paideia plan. If they are successful in improving performance in "academic" areas, other school systems may elect to adopt the plan.

Discipline Based Art Education is following a similar course. The J. Paul Getty Trust is sponsoring development of DBAE. Individual school systems have involved personnel in DBAE training and have been implementing the program in their schools (McFee 1984). Should they be successful in improving student performance in the four roles of the visual arts, then DBAE may spread to other schools and help guide the course of instruction for training art teachers. The Getty Institute has an added edge over the Paideia group in that it has strong financial support to offer to encourage the development of programs that are sympathetic with the DBAE philosophy.

Unfortunately, for those who are not won over by the Paideia philosophy and who never heard of the Getty Institute, the proposal set forth in A Nation at Risk will have the greatest influence. Giving more time and emphasis to the New Basics means taking it away from less valued subjects, such as art. Giving more time and emphasis to the New Basics is the easiest, most obvious, and most politically safe thing to do. In this case, excellence in education will not mean 
excellence in art education.

\section{References}

Adler, M. J. (1982) Paideia problems and possibilities: A consideration of questions raised by the paideia proposal. New York: Macmillan.

Adler, M. J. (1982) The paideia proposal: An educational manifesto. New York: Macmillan.

Broudy, H. S. (1976). Arts education as aesthetic perception. In Hines, G. Clark, W. D. Greer, and R. Silverman (Eds.), The aesthetic eye: Generative ideas. Downey, C A: Office of Los Angeles County Superintendent of Schools.

DiBlasio, M. K. (1985). Continuing the translation: Further delineation of the DBAE format. Studies in Art Education, 26 (4), 197-205.

Ecker, D. W. (1966). The artistic process as qualitative problem solving. In E. W. Eisner \& D. W. Ecker (Eds.) Readings in Art Education. Waltham, MA: Blaisell.

Gardner, D. (Ed.). (1983) A nation at risk: The imperative for educational reform. Washington DC: National Commission For Excellence In Education, USGPO.

Getty Center for Education in the Arts (1985). Beyond creating: The place for art in America's schools. Los Angeles, CA: The J. Paul Getty Trust.

Greer, W. D. (1984). Discipline-based art education: Approaching art as a subject of study. Studies in Art Education, 25 (4), 212-218.

Lovano-Kerr, J. (1985). Implications of DBAE for university education of teachers. Studies in Art Education, 26 (4), 216-223.

McFee, J. K. (1984) An analysis of the goal, structure, and social context of the 1965 Penn State Seminar and the 1983 Getty Institute for Educators on the Visual Arts. Studies in Art Education, 25 (4), 276-280. 
Sizer, T. (1984). Horace's compromise: The dilemma of the American high school. Boston, MA: Houghton Mifflin.

Wilson, B. G. (1966). An experimental study designed to alter fifth and sixth grade students' perceptions of paintings. Studies in Art Education, 8 (1), 33-42. 